\title{
Webにおける学習者のナビゲーションプラニング を支援する環境について
}

\section{A Learner-Centered Navigation Planning with Web-based Learning Resources}

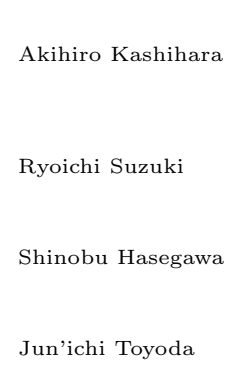

大阪大学産業科学研究所

The Institute of Scientific and Industrial Research, Osaka University

kasihara@ai.sanken.osaka-u.ac.jp, http://www.ai.sanken.osaka-u.ac.jp/thome2/kasihara/

(同上上)

suzuki@ai.sanken.osaka-u.ac.jp, http://www.ai.sanken.osaka-u.ac.jp/thome2/suzuki/

(同上上)

hasegawa@ai.sanken.osaka-u.ac.jp, http://www.ai.sanken.osaka-u.ac.jp/thome2/hasegawa/

(同上)

toyoda@ai.sanken.osaka-u.ac.jp, http://www.ai.sanken.osaka-u.ac.jp/thome2/toyoda/toyoda.html

keywords: navigation planning, path preview, web-based learning resources, hyperspace, self-directed learning environment

\section{Summary}

Web-based learning resources provide learners with hyperspace where they can navigate in a selfdirected way to learn the contents included in the Web pages. The navigation involves making a sequence of the pages visited, which is called navigation path. However, learners often fail in making the navigation path due to a cognitive overload, which is caused by diverse cognitive efforts at comprehending the contents in Web pages, and monitoring the navigation process such as planning and reflection of navigation path. In the self-directed learning, in particular, it is difficult for learners to maintain the navigation monitoring. Focusing on navigation planning, this paper addresses the issue of how to facilitate learners' navigation monitoring to promote their learning in hyperspace provided by Web-based learning resources. Our approach to this issue is to provide learners with a space, in which they can see through the learning resources to plan a navigation path, apart from hyperspace. In this paper, we also demonstrate an assistant system for the navigation planning, which is composed of hyperspace map, page previewer, and path previewer. These facilities give learners an overview of Web pages and navigation path to help them make a navigation path plan without visiting Web pages in hyperspace. This paper also describes a case study with the assistant system. The results indicate that the system facilitates navigation particularly in a more complicated hyperspace.

\section{1.は じめに}

WWW (World Wide Web , 以下 Web と記す) には， 現在膨大な量の情報リソースが公開されており，これら の中には学習や教育に利用可能なリソース (学習リソー スと呼ぶ）か数多く存在している.こうした学習リソー スは , 利用時の時間的 , 空間的制約が小さいというメリッ トから, 学校教育において, また遠隔学習や生涯学習を 実現する手段としても，今後ますます利用される機会が 増えることが予想される.このように, Web を学習活動 のプラットフォームとみなす Web-based Learning は , 学習支援の分野でも非常に重要な研究課題となっている. 本研究も, 光の一つとして, Web における既存の学習リ ソースを用いて学習者が主体的に行う学習に対し, 効果 的な支援手法を提案することを目的としている.
Web 上の学習リソースは, 多くの場合, 複数の Web ページとページ間を連結するリンクからなるハイパー空 間を学習者に提供する . 学習者は, ある学習目的のもと に,この空間内をナビゲーションしながら, 学ぶジきぺー ジおよび光の順序 (ナビゲーションパス) を主体的に決 め, 学習リソースが提供する学習内容を順次理解してい くことができる [Nielsen 90, Thuering 95]. 光のため， 個々の学習者に応じた理解が可能であり, 高い学習効果 を期待することができる [Fischer 98] .

一方，こうした主体性を伴う学習では, ページ内容の 理解に加えて, 光のメ夕認知的な活動として, ナビゲー ションパスの見通しを立てたり (ナビゲーションプラニ ング），これまでのナビゲーション過程を振り返ってどの 程度学んだのかを認識する (リフレクション) といった ナビゲーション過程のモニタリングを同時並行的に行う 
必要がある [Cunninghan 93, Kashihara 99] . しかしな がら，モニタリングを維持・継続することは容易ではな く [Hammond 93]，しばしばナビゲーションに行き詰ま りが生じる .このようなナビゲーションの行き詰まりは， ハイパー空間での学習支援において解決すべき中心的課 題となっている [Thuering 95] .こうした問題を解決す るためには, 学習者によるナビゲーション過程のモニタ リングを促進する方法を検討する必要がある [Hammond 93].また，ハイパー空間における主体的学習ではモニタ リングが重要な役割を担うことから，モニタリング能力 を高めることも考慮する必要がある．

以上のような観点から, 本研究では, Web における既 存の学習リソースを用いた学習を, ページ内容の理解と ナビゲーション過程のモニタリングに明確に区別し，モ ニタリングに学習者の注意を向けさせる方法を検討して いる [Kashihara 00, Suzuki 01] .特に，モニタリング の中でもナビゲーションプラニングに焦点を当て , ナビ ゲーションパスの見通しを立てることができるように支 援する手法について検討している．なお，学習の主体性 を重視する立場から，学習者中心 (Learner-Centered) の設計方針のもと，学習者自身がナビゲーションプラニ ングを行い，弚れを支援する環境を目指している．本研 究では, こうした支援をナビゲーションプラニング支援 と呼ぶ .

本論文では, このようなアプローチのもと, ナビゲー ションプラニング支援手法および支援システムについて 述べる. 通常，ナビゲーションパスの見通しを立てるた めには, Web ページの内容およびページ間の関係を把握 することが必要である.乥こで, 本支援手法では, これら の情報を提供するために , ハイパー空間の地図から学習 者が選択したページおよびナビゲーションパスの概要を プレビューとして表示し, 学習者によるナビゲーション パスのプラニングを補助する．これによって，学習者は 実際にWeb ページの内容を学んでいく前に, 先行オーガ ナイザとしてナビゲーションパスの概要を知ることがで き [Ausubel 61]，ハイパー空間ではプランに光ってペー ジ内容を理解することに集中できると期待される . 開発 した支援システムでは, こうしたページ内容の理解に対 する支援も提供している .

また，本論文では，ナビゲーション過程に対する本支 援手法の有効性を調べたケーススタディについても述べ る.この調査では，本支援システムを用いて学習した場 合と Web ブラウザのみで学習した場合における被験者 のナビゲーション過程を比較した，光の結果，本支援手 法がより複雑なハイパー空間を有する学習リソースにお いて, 学習者のナビゲーション効率を高める可能性があ るという知見が得られた .

以下，2．では, ハイパー空間での学習および必要と される支援手法について考察する．３．では, ナビゲー ションプラニングを支援する枠組みおよび支援システム
について述べる．4．では, 開発した支援システムを用 いて , ナビゲーションプラニング支援手法の有効性を調 ベたケーススタディについて述べる．5．では，ハイパー 空間における見通しの提供という点から, 関連研究との 比較を踏まえた本支援手法の位置づけ，ならびに問題点 について議論する．最後に，6．では，本論文の結論お よび今後の課題について論じたい .

\section{2. ハイパー空間における学習}

ここでは,ハイパー空間での学習過程を概観し，これ までに提案されている支援手法を含めて, 必要となるナ ビゲーション支援について考察する .

\section{$2 \cdot 1$ 学習過程と難しさ}

ハイパー空間における学習の特徵は, 空間内でのナビ ゲーションを伴い, 学んだ知識を構成的に積み上げてい くことができる点にある.この過程では, 学習目的の達 成に向けて，学習者はページ間のリンクをたどりながら， 主体的に学ら゙ベきページおよびナビゲーションパスを決 めることになる．光して，訪れたページごとに学んだ内 容を関係づけて知識を構成していくことができる．この ように，知識の積み上げはナビゲーションパスに大きな 影響を受ける．したがって，ナビゲーションパスを決め ることは, ハイパー空間における学習の中でも非常に重 要なプロセスであるといえる [Hammond 93] .

また ,ハイパー空間における学習は,ナビゲーション中 に訪れたページの内容の理解および理解した内容の関係 づけと, 光のメタ認知的な活動としてナビゲーション過程 のモニタリングに分けて考えることができる [Hammond 93, Thuering 95] . モニタリングは,さらに以下の二つ に大別することができる .

・ナビゲーションプラニング : 学習目的達成のために 訪れるべきページおよび光の順序を計画する．

・リフレクション : これまでのナビゲーション過程を 振り返って, 学んだ知識・未学習の知識, 学習目的 の達成度などを確認する。

ハイパー空間では, これらの種類の異なる学習活動を 同時並行的に行うことになる，弚のため，学習にかかる 負荷は大きく，しばしばナビゲーションに行き詰まりを 生じる [Nielsen 90, Thuering 95] .これは, ハイパー空 間が複雑すぎたり，ページ内容の理解に注意が奪われる ことでナビゲーション過程のモニタリングを維持・継続 することが容易でなくなることが主な原因と考えられる． つまり,ナビゲーションパスの見通しを立てることが困難 となったり，何を・どのように学んだのかが不明瞭になる ことで, 次のページを選択できなくなってしまう [Suzuki 01, Kashihara 99].こうした難しさを乗り越え，主体的 に学習を進めるためにはナビゲーション過程のモニタリ ング能力が不可欠であるといえよう．また，行き詰まり 
の解消を支援するためには, 学習者によるモニタリング を促進することが必要である [Hammond 93] .

本論文では，モニタリングの中でもナビゲーションプ ラニングに着目する.ナビゲーションプラニングでは, 学 習目的を達成するために，いかにナビゲーションパスの 見通しを立てるかが重要な問題となる．以下では, この ような観点から，ナビゲーション支援手法について検討 してみたい .

\section{$2 \cdot 2$ ナビゲーション支援}

これまでの関連研究では, 学習者の学習文脈を踏まえ て次に学ぶべき適切なページを推薦するハイパーメディ ア (Adaptive Hypermedia) [Brusilovsky 96]や , ハイ パー空間に内在する概念間の意味的関係を記述した概念 地図 (Concept Map) [Gaines 95] が提案されている.こ れらは , ハイパー空間におけるナビゲーションの行き詰 まりを解消するために , ナビゲーションパスの見通しを 与える強力な手段と考えられる．ただし，基本的にはナ ビゲーションプラニングを学習者にできるだけ意識させ ずに,ページ内容の理解や理解した内容の関係づけに注 意を促す手法であるといえる．また，学習者のナビゲー ション過程を過度に誘導してしまって，本来期待される 高い学習効果を損ねてしまうという問題が指摘されてい る [Thuering 95] .さらに ,ハイパー空間でのモニタリン グ能力を高めるという教育的な観点も考慮されていない .

これらの問題点を解決するためには,ナビゲーションパ スの見通しを与えるのではなく, 学習の主体性をより助 長するような支援手法を考える必要がある [Cunninghan 93].特に，Webにおける既存の学習リソースでは, ペー ジ間の意味的関係が明記されていない場合が多いため，こ れを基盤情報として用いる従来の支援手法ではナビゲー ションパスの見通しを提供することは困難である [Zeiliger 99].したがって，こうした学習リソースでは，学習者に よる主体的なナビゲーションプラニングを助長する必要 性は高いといえる。

このように, 学習の主体性を重視する場合 , ナビゲー ションパスの見通しを立てることに集中できる場を学習 者に提供して , ナビゲーションプラニングを促進するこ とが必要であろう．こうした支援によって，プラニング 能力の向上も期待することができる [Suzuki 01] .

この他, ナビゲーションパスの見通しを与えることが 可能な従来の支援手法として，ページをノードで表現し， ページの連結関係をネットワーク表現したハイパー空間 地図が挙げられる [Domel 94] . 学習者は, 実際にページ を訪れる前に，この地図を見ながら，どのページを学ぼ うとするのかを考えることができる．しかしながら，こ の地図は，本来ハイパー空間における現在の位置や，目 標となるページまでの経路を確認するためのものであっ て，知識を積み上げるためのナビゲーションパスを見通 すには十分な情報が与えられているとは言い難い .つま
り，学習目的の達成に向けて，どのパスをたどるべきか についての見通しを立てるためには，ハイパー空間にあ るページの存在やページ間のつながりといった情報だけ でなく, ページの内容やページ間の意味的な関係も把握 することが不可欠である [Kashihara 00] . したがって， ナビゲーションプラニングに必要な情報として，これら を学習者か把握できるように支援する必要がある。

\section{3. ナビゲーションプラニング支援}

以上の考察を踏まえて, 本研究では, Web 上の学習リ ソースに対して，学習の主体性を重視するという観点か ら，ハイパー空間におけるページ内容の理解とナビゲー ションプラニングとを明確に区別し，学習者自身にナビ ゲーションパスのプラニングを行わせるような支援手法 を提案している [Suzuki 01]. 本支援手法では, 学習リ ソースカ提供するハイパー空間の地图を提示するととも に, 学習者か地図上で選択した Web ページやパス (ペー ジ列）の概要情報をプレビューとして表示することで， ページの内容やページ間の意味的な関係を把握すること を補助する枠組みを提供している．本章では，こうした 学習者主体によるナビゲーションプラニングに対する支 援の枠組み，および支援システムについて述べる．なお， 本研究では, Web の単一サイト内で，ある学習トピック を記述したハイパードキュメントを学習リソースと呼ぶ .

\section{$3 \cdot 1$ 枠 組 み}

本ナビゲーションプラニング支援では，概念的にはナ ビゲーションプラニングを行うための空間を，ページ内 容の理解を行うハイパー空間から明確に区別して捉えて いる.ナビゲーションプラニングの空間では, 学習者自身 が学習目的を立て, 弚の達成を可能とするナビゲーショ ンパスの見通しを得るために, ハイパー空間地図上で学 ぼうとするページやパスを選択する .この際，選択された ページの概要情報を表示 (ページプレビュー)して, 学習 者によるページ内容の把握を支援する . また , プレビュー されたページを並べて表示 (パスプレビュー) すること でページ間の意味的な関係の把握を促すとともに,ナビ ゲーションパスのプラン作成を支援する．さらに，立て られたプランに光って，ハイパー空間でページ内容を理 解するように学習者を促し, 途中でプランの修正・棄却 が必要となった場合 , ナビゲーションプラニングの空間 に立ち戻ってリプラニングを行うことを可能にしている．

以上のような枠組みにしたがって , ナビゲーションパ スプラニング支援システムを開発した . 図1に, ユーザ インタフェイスを示す. 本システムは, ハイパー空間地 図 , ページプレビューア , パスプレビューアから構成さ れている.まず, 学習者がWeb 上の学習リソースを選択 すると, 図 1 (a)のように, 光のハイパー空間地図が自 動生成される .この地図では, 選択された学習リソース 


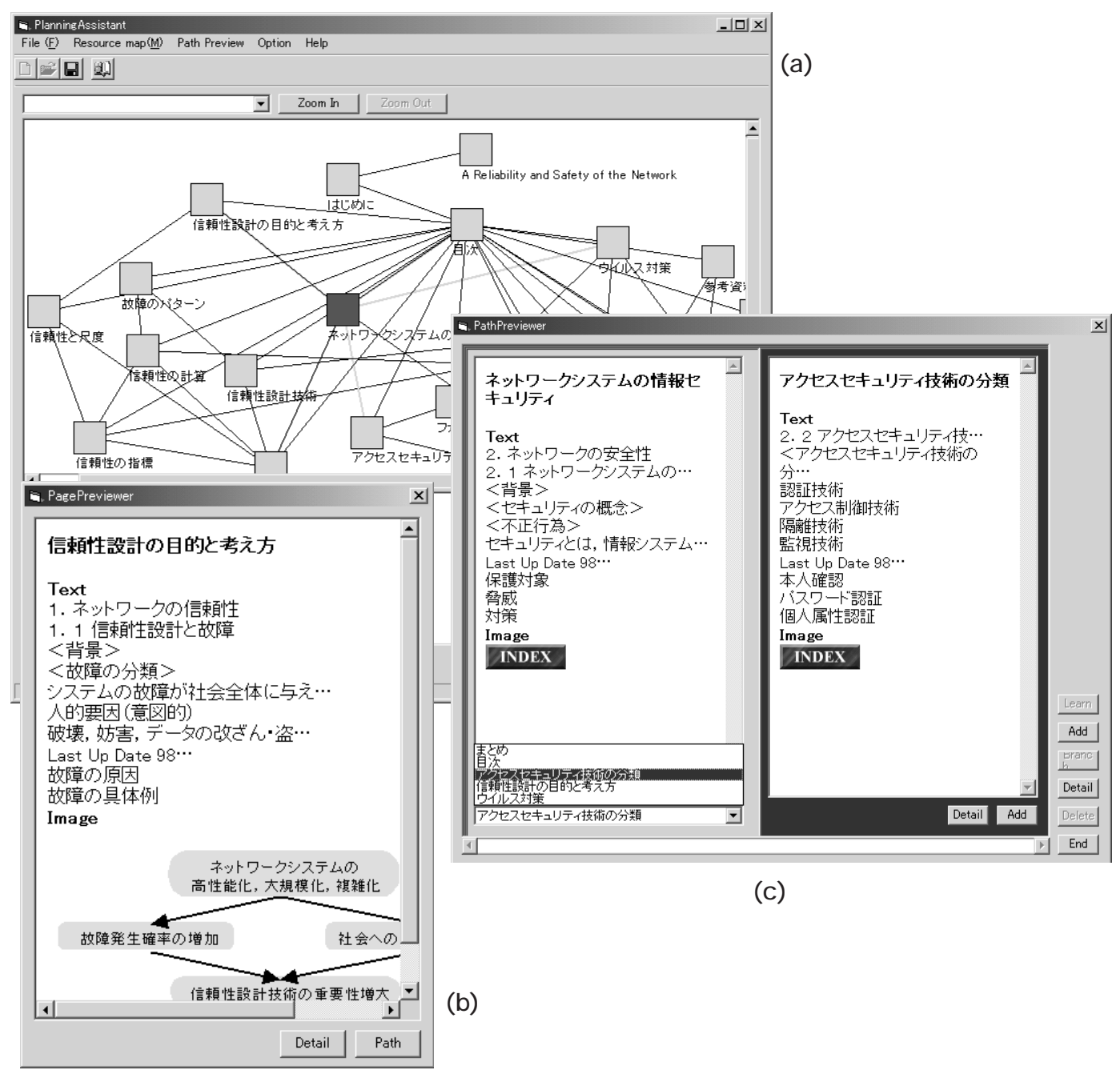

図 1 ナビゲーションプラニング支援インタフェイス

が置かれている Web サイト内に限定して，学習リソー スに含まれるページが表現されており，光の外部のサイ トへのリンクは省略される . 地図内の各ノードは, 対応 する Web ページを表し，弚の HTML ファイルの Title タグの情報がページタイトルとして記述されている .

ハイパー空間地図上において , 任意のノードをマウス クリックすると, ページプレビューアが起動し, 対応す るWebページの概要が図 1 (b) のように新しいウィンド ウ (ページプレビューウィンドウ) に表示される．マウ スで選択されたノードは, 地図上では色づけされ，どの ページのプレビューを表示しているのかが分かるように なっている . 学習者は, いくつかのページのプレビュー を繰り返し表示しながら , ナビゲーションパスの始点と なるページを決めることになる．

ナビゲーションパスの始点が決まると，パスプレビュー アが起動し，ページプレビューウィンドウが図 1 (c) の ようにパスプレビューウィンドウに変化する .このウィ ンドウ上で, 学習者は始点ページから順次学ぼうとする ページの列を作成することができる .このページ列がナ ビゲーションパスのプランを表現する . パスプレビュー アは, 現在のページ (図 1 (c) では一番左端のページ)
プレビューの下に , 弚のページに隣接するページのタイ トルをリスト表示 (リンクリスト) する .このリストか ら任意のタイトルを選択すると，現在のページの右側に， 選択ページのプレビューが表示される .このプレビュー を見て学ぶベきページでないと判断した場合は, 再度リ ンクリストからタイトルを選択し直す．所望のページで あれば , パスプレビューウィンドウの右側に配置される $A d d$ ボタンを押すことで, 弚のページをナビゲーション パスに追加することができる．これらの操作を繰り返す ことによって，プランが作成される . パスプレビューア では，このようにリンクリストによってハイパー空間地 図に戻らず，学習者はナビゲーションパスのプラン作成 に集中することができる .

さらに, 本システムでは, 学習者がプランに光って , 八 イパー空間でページ内容の理解を進める過程を支援する ために , ナビゲーションコントローラを提供する . 図 2 に，光の支援の樣子を示す。

学習を開始すると，図 2 (a) のようにナビゲーション コントローラが現れるとともに, プランの始点ページが Web ブラウザ上に表示される . 図 2 では , (b) に示され たプランの始点ページが (c) の Web ブラウザに表示され 
(c) Webブラウザ

(b) パスプレビューウィンドウ

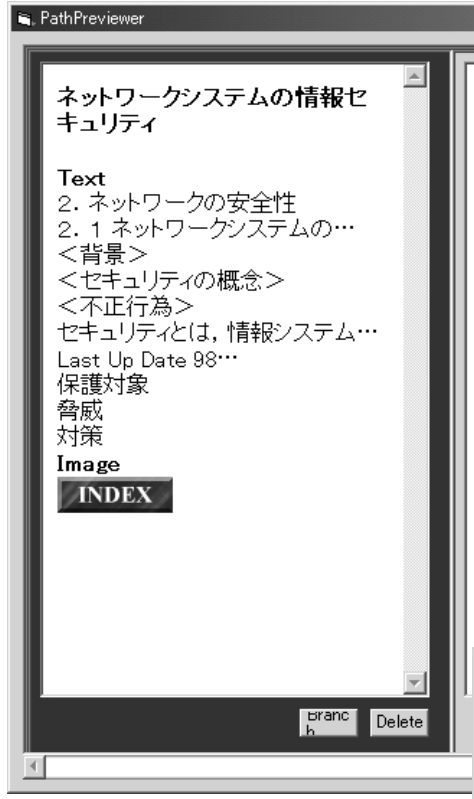

2.2アクセスセキュュ

くアクセスセキュリ

分…

分多俅御技術

隔離技術

監視技術

Last Up Date 98 .

本人磪認

ハイワード認証

個人属性認証

Image

INDEX

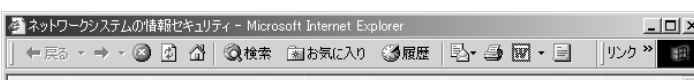

\section{BACK INDEX NEXT}

\section{2. ネットワークの安全性}

2. 1 ネットワークシステムの情報セキュリティ

<背景〉

近年,ネットトークシステムの利用分野が嘛丸しており，重要な情報にネ 清郝の安

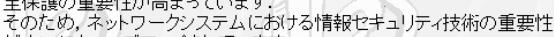

が大いにタローズアッフされていはす。

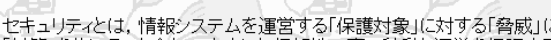

〈セキュリティの概念〉 「対策を施して, 安全か门安定した信賴性の高い榢動運営を保証する

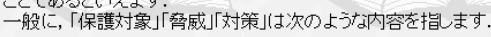

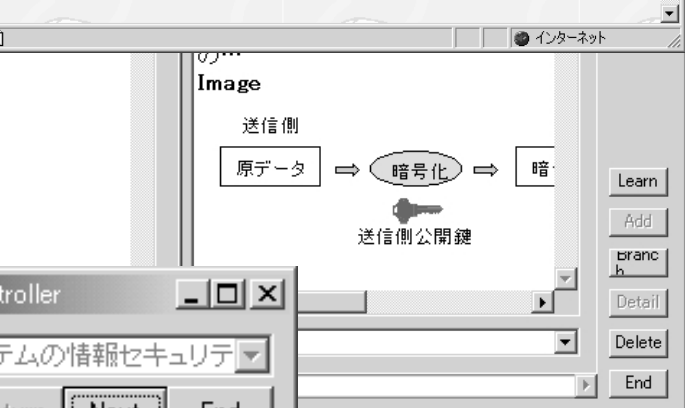

(a) ナビゲーションコントローラ

図 2 プランに基づくページ内容の理解支援

ている .このコントローラにある Next ボタンを押すこ とで, プラン上の次のページがブラウザ上に表示される . また，Back ボタンを押せば，ブラウザで閲覧してきたー つ前のページに戻ることができる．なお，学習者は必ず しもプラン通りに学習を進める必要はなく, プランに含 まれないページを Web ブラウザ上で閲覧していくこと もできる .この場合は , ナビゲーションコントローラ上 に，プランから外れたことを示すアイコンか現れ，学習 者に注意を促す .プラン上のページに復帰したい場合は， ナビゲーションコントローラにある Return ボタンを押 すことによって，プランから外れたページに戻ることが できる、また，プラン実行中にプランを修正・棄却した い場合は，いつでもパスプレビューアを起動して，Web ブラウザで閲覧している現在のページからリプラニング を開始することができる .

以上のような枠組みで, 学習者はナビゲーションプラニ ングを行い,プランに弚った学習を行うことができる。以 下では, 本支援手法の中心的役割を担うページプレビュー およびパスプレビューについて詳述する .

\section{$3 \cdot 2$ ページプレビュー}

Web ページの内容を代表する情報は, 乥の HTML ファ イル内の主要なタグで示されているという仮定のもとで，
表 1 ページプレビューに用いる HTML ファイルのタグ

\begin{tabular}{|c|c|}
\hline タグの種類 & 意味 \\
\hline $\begin{array}{l}\text { テキスト情報 } \\
\text { - Title } \\
\text { - H1〜 H3 } \\
\text { - Font Size/Color/Face }\end{array}$ & $\begin{array}{l}\text { ページのタイトル } \\
\text { 見出し } \\
\text { フォントのサイズ绝種類 }\end{array}$ \\
\hline $\begin{array}{l}\text { イメージ情報 } \\
\text { - Img }\end{array}$ & 画像ファイル \\
\hline $\begin{array}{c}\text { リンク情報 } \\
\text { - A href }\end{array}$ & 他のページへのリンク \\
\hline
\end{tabular}

表1 に示すタグを検索し，タグ付けされた情報を取り 出して, ページプレビューとして表示する．

Web ページから抽出される情報は, テキスト情報，イ メージ情報，他のページへのリンクに分けることができ る.まず，テキスト情報については，HTML ファイル内 で, Title タグ, H1〜H3 タグ, Font (サイズ, 色 , 種類) タグに着目し，タグ付けされた語彙・文章や，色づけさ れたり，フォントの種類が異なる部分を抽出する . 取り 出乥うとする文章が長い場合は, 先頭から数文字までを 取り出す.また , HTML ファイル中に , これらのタグ数 が多い場合は，抽出するタグの数を決めておいて，Title タグ, $H 1$ H3 タグの順に優先して情報を取り出す.

イメージ情報については，現在のところ, Img タグにつ 
けられた画像ファイルのサイズが最も大きいファイルを抽 出するようにしている．リンク情報については, HTML ファイル内のすべての A href タグを検索し , タグ付けさ れた URL 情報を取り出す. 兴のうち, ハイパー空間地 图の範囲で，URLが指す Web ページ (現在のページに 隣接しているページ) の Title タグからタイトル情報を 抽出する .この情報は, ページプレビューの情報として ではなく, 次のページへのリンクとしてパスプレビュー アが利用する。

ハイパー空間地図において任意のノードが選択される と,ページプレビューアが起動し, 弚のページプレビュー を表示する . 図1 (b)のように, ページプレビューウィ ンドウの右下部には Detail ボタンがあり，表示されたプ レビューでページの内容を把握できない場合, このボタ ンを押すことでWeb ブラウザに光のページの全内容を閲 覧することができる．また，ナビゲーションパスの始点 が決まると，Path ボタンを押すことでページプレビュー ウインドがパスプレビューウィンドウに切り替わり,ペー ジ列の作成を開始することができる .

\section{$3 \cdot 3$ パスプレビュー}

パスプレビューウインドウでは, プレビューされたペー ジを学習者が順次ウィンドウ内に追加することによって， ページ列が作成される，弚の際，ページプレビューアに よって作成された隣接ページのタイトル情報をリンクリ ストとして，图１（c)のようにドロップダウンメニュー の形で現在のページプレビューの下部に表示する .この リストによって，パスプレビューウィンドウでのページ 列の作成を支援する .

まず，リンクリストから学ばうとするページを選択す ると,ページプレビューアによって兴のページプレビュー が生成され，図 1 (c) のように現在のページの右側に表 示される.このページプレビューを見て，プランに含め る場合はパスプレビューウィンドウ右端にあるボタン群 の中から $A d d$ ボタンを選択する . プランに含めない場合 は, リンクリストから再度別のページを選択することに なる．また，Delete ボタンを押すことによって，一度パ スに含めたページを削除することも可能である．さらに， あるページからナビゲーションパスを分岐させたり，プ ランを実行する前に新たに別のナビゲーションパスのプ ランをたてることもできる .

以上の操作を繰り返し行うことによって ,ナビゲーショ ンパスのプランを作成し , パスプレビューウィンドウ右 端にある End ボタンでプラン作成を終了することができ る。また，Learn ボタンを押すと，ナビゲーションコン トローラが起動し , プランに光ったページ内容の理解を 開始することができる .
表 2 実験で用いた学習リソース

\begin{tabular}{c|cc}
\hline & $\begin{array}{c}\text { Learning } \\
\text { Resource1 }\end{array}$ & $\begin{array}{c}\text { Learning } \\
\text { Resource2 }\end{array}$ \\
\hline $\begin{array}{c}\text { ページ数 } \\
\text { 1ページあたりのの } \\
\text { リンク数 } \\
\begin{array}{c}\text { ホームページから } \\
\text { 末端ページまでの }\end{array}\end{array}$ & 32 & 161 \\
\begin{tabular}{c} 
最長距離 \\
\hline
\end{tabular} & 3 & 2.2 \\
\hline
\end{tabular}

Learning Resource1の学習トピック : 生命の進化と宇宙論 Learning Resource2の学習トピック : 地球と生物の誕生

表 3 実験条件

\begin{tabular}{c|l|cc}
\hline \multirow{2}{*}{} & \multicolumn{2}{|c|}{ 条件名 } & \multicolumn{2}{|c}{ 実験条件 } \\
\cline { 3 - 4 } & & ハイパー空間 & 支援システム \\
\hline ケース & Simple-With & 簡単 & 有 \\
スタディI & Simple-Without & 簡単 & 無 \\
\hline ケース & Complicated-With & 複雑 & 有 \\
スタディII & Complicated-Without & 複雑 & 無 \\
\hline
\end{tabular}

\section{4. ケーススタディ}

\section{$4 \cdot 1$ 目 的}

本ケーススタディの目的は, Web 上に既存の学習リ ソースを用いて，本支援手法がハイパー空間での主体的 学習におけるナビゲーションの促進に貢献する可能性を 調査することにある．ここでは，本支援システム利用の 有無のもと，ハイパー空間で学習目的を達成するために ナビゲーションパスを見出すまでの効率 (ナビゲーション 効率) を比較して，本支援手法の有効性を調へた 。なお， ハイパー空間がより複雑な学習リソースを用いた場合と より簡単な学習リソースを用いた場合に分けてこの調査 を実施し，本支援手法が有効に働く範囲についても調べ た．本調査では，前者をケーススタディI，後者をケース スタディII と呼ぶことにする．

\section{$4 \cdot 2$ 準 備·条 件}

本調査では, 表 2 に示すように, Web 上の学習リソー スを二つ用意した. 各リソースに含まれるぺージ数， 1 ページあたりのリンク数 (Nextや Backなどのナビゲー ションを誘導するようなリンクは除いて数えている.)， および各リソースのホームページから最も離れた末端と なるページまでの距離は表に示すとおりである .これら の数値をもとに，本調査では Learning Resource 2 のほ うがより複雑なハイパー空間を持っていると判断した．

また，調査に関わる要因として，ケーススタディI お よびIIのいずれにおいてもシステム利用をあげ，利用の 有・無の 2 水準とした . 表 3 に, 各ケーススタディで の1要因 2 水準の実験条件を示す.

被験者については, 理工系大学生・大学院生 40 人を 選び，各ケーススタディに対して 20 人ずつ割り当てた . 
各ケーススタディでは，被験者間計画となるように，各 実験条件に 10 人ずつ割り当てた .いずれの条件におい ても，Web ページ内容を閲覧するために，Web ブラウ ザを提供した .

なお，学習内容についての既有知識の程度やインター ネット利用経験が被験者間で大きく異なると, 調査結果 に影響を与えることになる，乥こで，本調査では，これ を避けるために，学習対象について馴染みか薄く, Web ブラウザの利用経験が 2 年以上の理工系の大学生・大学 院生を被験者として選定し，ケーススタディI・IIおよび ケーススタディ内の実験条件に対してランダムに割り当 てた .このような割り当てによって，各実験条件の被験 者グループ間における既有知識やインターネット利用経 験の差異が実験結果に影響を及ぼさないと仮定し，本調 査を実施した。

また, 各条件下での調査を開始する前に, 各被験者に は学習目的として，学習リソースごとに問題を与えた 問題は，ページに記述された学習項目間の関係を説明す るように問うもので, ハイパー空間において隣接する 2 ページあるいは3ページを関連づけて钅の答えを見つけ ることができるものである .このため，個々のページ内 容だけではなく，ページ間の関係を考えなければ答える ことができないものとなっている．また，本支援システ ムを用いる場合, ハイパー空間地図, ページプレビュー， パスプレビューだけで問題の答えとなるページを特定す ることはできないようになっている．

例えば，実際に用いた問題として，以下の問題がある．

・マグマができる場所を挙げ，乥れらについてマグマ との関連を説明せよ .

この問題を解決するためには, マグマができる場所とし ての海嶺, プレートを見つけ，乥れらがどのようにマグ マと関わるかを説明する必要がある．この例では，「マグ マができる場所」という記述を含むマグマ形成プロセス のページと海嶺やプレートのページの3つのページは隣 接している (海領とプレート間にもリンクがある) が, 海 嶺やプレートのページだけを見てもマグマができる場所 であるとは特定できず，マグマ形成プロセスのページか らこれらのページを眺めるナビゲーションパスを通して 問題に対する答えを得ることができる .

また，この例ではハイパー空間地図に「マグマができ る場所」という明確な記述はないが，マグマに関連する複 数のページに対するページプレビューやパスプレビュー を参照することによって，マグマができる場所およびそ の候補についての情報を得ることができる．しかしなが ら，弚れらの候補のうちマグマができる場所はどれなの か，またマグマとどのように関わるのかといった情報は 実際にWeb ページを閲覧しないと得られないようになつ ている.このように ,ナビゲーションプラニングを通し て問題解決の手がかりは得られるものの，問題の答えを 見つけるためには Web ページを閲覧することが必要と
なるような問題を与えた .

\section{$4 \cdot 3$ 手順}

各被験者に対する調査の手順は，ケーススタディI お よびII ともに以下のとおりである .

(1) 支援システム有りの条件では, システムの使い方 の説明を提示した .

(2) 問題を 2 問与えて, 解答するように指示した . こ の際，答えに必要となる内容を含む Web ページを特定 させ ，光のぺージの URL をコピーするメモを提供した . また，支援システム利用有りの条件では，支援システム を用いてナビゲーションパスのプランを立て , Web ブラ ウザ上で Web ページ内容を閲覧しながら解答するよう に指示した 。

(3) 与えた全問題の解答を終えたと学習者が自己申告 した場合，あるいは制限時間を経過した場合，学習を終 了したと見なした．乥して，ナビゲーション効率を図る データとして，弚の時点でのメモの内容を取得した . ま た，Web ブラウザで閲覧したページ数のデータを取得 した。

各条件とも，解答の制限時間を 15 分とした . また，本 調査では, 学ふぶベき内容を記憶することではなく，ナビ ゲーションの結果見つけることができたかどうかを調べ ることを重視し，問題の答えとなる内容か記載されたぺー ジを特定させて問題に対する解答とした .

ナビゲーション効率を図るデータとしては, 問題に対 する解答率と，閲覧した Web ページ数およびページへ の再訪問回数を取り上げた [Tauscher 97] . 解答率につい ては, 次の3つの指標に分けた . まず, Achievement は， 全体の問題数に対する制限時間以内に解答した問題数の 割合である.Accuracy は，解答した問題数に対する正解 の割合である .Efficiency は, 全体の問題数に対する正 解の割合であり, Achievement と Accuracy の積として 表現される .なお, 正解は, 問題の答えを含む複数ぺー ジのうち，被験者によって特定された割合で表現した．

以上の設定のもとで，「本支援手法は，より複雑なハイ パー空間においてナビゲーション効率を高めることに貢 献する」という仮説を立てた 。

\section{$4 \cdot 4$ 結 果}

表 4 (a) と表 5 (a) に，ケーススタディI と II の各 条件下での解答率の平均を示す.これらの表からも分か るように，より簡単なハイパー空間を有する学習リソー スでは, システムを用いた場合 (Simple-With) と用い なかった場合 (Simple-Without) では，解答率に有意な 差異は見られなかった .一方，より複雑なハイパー空間 を持つ学習リソースでのナビゲーションにおいて , シス テムを用いた場合 (Complicated-With) のほうが, 用い なかった場合 (Complicated-Without) に比べて解答率 の值が大きくなっており，分散分析の結果有意な差が見 
表 4 ケーススタディIの実験結果

(a) 問題に対する平均解答率

\begin{tabular}{l|ccc}
\hline \multicolumn{1}{c|}{ 実験条件 } & Achievement & Accuracy & Efficiency \\
\hline Simple-With & $90 \%$ & $96 \%$ & $86 \%$ \\
Simple-Without & $98 \%$ & $98 \%$ & $96 \%$ \\
\hline
\end{tabular}

(b) 全ページ数に対する閲覧ページの割合

\begin{tabular}{l|l}
\hline \multicolumn{1}{c|}{ 実験条件 } & \\
\hline Simple-With & $32 \%$ \\
Simple-Without & $47 \%$ \\
\hline
\end{tabular}

(c) 閲覧ページの平均再訪問回数

\begin{tabular}{l|l}
\hline \multicolumn{1}{c|}{ 実験条件 } & \\
\hline Simple-With & 2.71 \\
Simple-Without & 3.72 \\
\hline
\end{tabular}

表 5 ケーススタディII の実験結果 (a) 問題に対する平均解答率

\begin{tabular}{l|ccc}
\hline \multicolumn{1}{c|}{ 実験条件 } & Achievement & Accuracy & Efficiency \\
\hline Complicated-With & $100 \%$ & $90 \%$ & $90 \%$ \\
Complicated-Without & $72 \%$ & $48 \%$ & $32 \%$ \\
\hline
\end{tabular}

(b) 全ページ数に対する閲覧ページの割合

\begin{tabular}{l|r}
\hline \multicolumn{1}{c|}{ 実験条件 } & \\
\hline Complicated-With & $7 \%$ \\
Complicated-Without & $25 \%$ \\
\hline
\end{tabular}

(c) 閲覧ページの平均再訪問回数

\begin{tabular}{l|l}
\hline \multicolumn{1}{c|}{ 実験条件 } & \\
\hline Complicated-With & 2.61 \\
Complicated-Without & 3.09 \\
\hline
\end{tabular}

られた (Achievement については F=8.62, p<.01,Accuracy については $\mathrm{F}=9.30, \mathrm{p}<.01$, Efficiency につい ては $\mathrm{F}=32.60, \mathrm{p}<.01)$.

次に, 表 4 (b) と表 5 (b) に, 学習リソースに含まれ る全ページ数に対して Web ブラウザで閲覧したページ 数の割合の平均を示す. 分散分析の結果, Simple-With と Simple-Without との間 $(\mathrm{F}=14.20, \mathrm{p}<.01)$ および Complicated-With と Complicated-Without との間 $(\mathrm{F}=$ $107.00, \mathrm{p}<.01)$ に有意な差が見られた . また，表 4 (c) と表 5 (c) に, 各条件下での Web ページの再訪問回数の 平均を示す. 分散分析の結果, Simple-With と SimpleWithout との間 $(\mathrm{F}=7.79, \mathrm{p}<.05)$ に有意な差が見られ た . Complicated-With と Complicated-Without との間 には，有意差は見られなかったが，Complicated-Withの ほうが平均再訪問数が少なくなっている．これらの結果 から，ハイパー空間の複雑さによらず，システムを用い た場合のほうが Web ブラウザで閲覧したページ数が有 意に少なく，また再訪問回数についても少なくなってい ることが分かる．

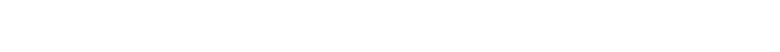
限定して，仮説は検証されたことになる．本調査結果か
表 6 ページの平均訪問回数

\begin{tabular}{l|rr}
\hline \multicolumn{1}{c|}{ 実験条件 } & \multicolumn{2}{|c}{ 訪問回数 } \\
\hline Simple-With & 38.0 & $(32 \times 0.32 \times 3.71)$ \\
Simple-Without & 71.0 & $(32 \times 0.47 \times 4.72)$ \\
\hline Complicated-With & 40.7 & $(161 \times 0.07 \times 3.61)$ \\
Complicated-Without & $164.6(161 \times 0.25 \times 4.09)$ \\
\hline
\end{tabular}

括弧内は 全ページ数 $\times$ 閲覽ページの割合 $\times$ (1+平均再訪問回数 $)$

ら，他の学習リソースにおいても有効な支援が可能であ ることが期待できるが ,このことについては $5 \cdot 2$ で議 論する .

\section{$4 \cdot 5$ 考 察}

本節では, 4 ・4の結果について考察し , 本ナビゲー ションプラニング支援の有効性について考えてみたい． 特に, 学習目的達成に向けてのナビゲーションパスの見 通しの提供およびナビゲーションの作業（ナビゲーショ ン負荷）の軽減という点から検討する．なお，ナビゲー ション負荷については Web ページの訪問回数という点 から考察する.

まず, ナビゲーションパスの見通しの提供については， 表 5 (a)，(b) の結果から，より複雑なハイパー空間にお いて本支援手法は学習目的の達成を促進するとともに，八 イパー空間では訪問するページ数を減少させ , ナビゲー ション過程をより集約的にすることがうかがわれる . こ れは, 本支援手法が学習目的の達成に向けてナビゲーショ ンパスを見通すことに役立つものとなっており，さらに 学習者はナビゲーションパスに対する良い見通しを持っ てハイパー空間内をナビゲーションしていることを示唆 していると考えられる

また，より簡単なハイパー空間では，表 4 (a)，(b)の 結果から，本支援手法はナビゲーション過程をより集約 的にするものの, 本支援システムがなくてもナビゲーショ ンパスの見通しを立てることが困難ではないことがうか がわれる．同時に，本支援システムを利用することがハ イパー空間でのナビゲーションに対して悪影響を及ぼさ ず, ナビゲーションに対する見通しを与えることができ るといえる。

次に，本支援システムを利用した場合のナビゲーショ ン負荷については, 表 4 (b)，(c)および表 5 (b)，(c)の 結果から，システムを利用しない場合に比べて ,ナビゲー ション負荷はハイパー空間の複雑さに関わらず軽減され ていることがうかがわれる.表 6 に, 各実験条件での再 訪問を含めたページの平均訪問回数を示す . この表から も分かるように，ハイパー空間が複雑になるほど，ナビ ゲーション負荷はより効果的に軽減されることが示唆さ れる .なお , 本支援システムの利用には , ナビゲーション 負荷だけでなく，ナビゲーションプラニングの作業 (プ ラニング負荷) を伴う．プラニング負荷は，ハイパー空間 が複杂隹になるにつれて増加し , ナビゲーションにも悪影 響を及ぼす可能性があるが , ハイパー空間地図を見やす 
くするなどの工夫を導入することで, ナビゲーションに 悪影響を及ぼさない程度に抑えることが期待できる。こ うしたプラニング負荷の軽減については,さらに詳細な 検討が必要であり，今後の課題としたい．

また，本支援システムを利用しない場合，ハイパー空 間でのナビゲーションに備えて, どのようにナビゲーショ ンすべきかを考えなければならないという学習者の心理 的な負担は小さくないと考えられる。特に，ハイパー空 間が複雑なほど，こうした負担は大きくなると考えられ る．一方，本支援手法では，ナビゲーションプラニング を行う環境を与えることによって，学習者はこれから学 ぼうとするナビゲーションパスの見通しを得ることがで きるため, ナビゲーションに備える際の心理的な負担も 軽減され，ハイパー空間における学習が促進されること が期待できる [Ausubel 61] .こうした心理的な負担の軽 減による効果は，ハイパー空間が複雑になるほど大きく なり，ナビゲーションの促進に良い影響をもたらすと予 想される .

以上のことから，本支援手法は，より複雑なハイパー 空間において, 学習者がナビゲーションパスの見通しを 立てることを有効に支援するとともに , ナビゲーション 負荷を軽減し，ハイパー空間でのナビゲーション効率を 高めることに貢献することができると考えられる．

\section{5. 議 論}

ここでは，ハイパー空間の見通しという観点から，ま ず関連研究との比較を通して, 本ナビゲーションプラニ ング支援手法の位置づけを試みる，次に , ナビゲーショ ンパスを見通す際の本支援手法の問題点および改善策に ついて考えてみたい .

\section{$5 \cdot 1$ 関連研究との比較}

これまでに提案されているハイパー空間の見通しを提 供する方法は, (1) 大域的な見通しを与える方法,(2) 局所的な見通しを与える方法，に大別することができる． 前者は, ハイパー空間全体を眺める表現を与えるもので, ハイパー空間地図が关の代表例である。これは,ハイパー 空間全体から見て現在学んでいるページの位置を確認し たり，目標となるページの選定や弚のページにいたるま での経路を確認するために用いられる . 後者は , 現在の ページから次のページの内容を見せようとするもので， 適応的ハイパーメディアやリンク先概要表示 [Kopetzky 99] が兴の代表例である .これらは，次のページを学習 文脈に合わせて推薦したり，次のページ内容をサムネイ ル化することで，次のページの選択を支援することを目 的としている.

一方, ハイパー空間において学習目的を達成するため に学習を進める場合 , ナビゲーションパスを決めること が非常に重要であり，いかにナビゲーションパスの見通
しを立てるが問題となる．しかしながら，2・2でも述 べたように，従来の支援手法ではこうしたパスの見通し を与えるには十分ではない．

本研究では,ハイパー空間地図およびページプレビュー によって大域的な見通しと局所的な見通しも与えるが，独 創的な点はこれらの中間的な見通しとしてナビゲーショ ンパスを明示的に見通す方法を提案したところにある。 こうしたパスを見通す支援は，ハイパー空間での主体的 学習では必要性が高く，弚の意義は大きいと考えられる。

\section{$5 \cdot 2$ 問題点と改善策}

本支援手法によって，学習者がナビゲーションパスの見 通しを得ることができるかどうかは, どの程度ページプ レビューがページ内容をうまく反映するかにかかってい るといえる．3・2でも述べたように, ページプレビュー の生成では, HTML ファイルの主要なタグにつけられ た情報が弚のページ内容を代表することを仮定している． この仮定をできるだけ満たすようにページ内容が記述さ れた学習リソースであれば, ページプレビューがうまく 機能し，適切にナビゲーションパスを見通すことができ る可能性は高くなる．４．で述べたケーススタディでの 学習リソースは，おおむねこの仮定を満たすようにペー ジ内容か記述されていたと考えられる．また，ケースス タディの結果から，この仮定を満たすような学習リソー スであれば有効な支援を提供できるといえよう．

しかしながら，この仮定を満たさないWeb 上の学習 リソースも少なくはないと考えられる．本支援手法では， こうしたリソースにおいてナビゲーションパスを適切に 見通すための情報を与えることは難しい，ただし，これ は本支援手法で扱えない範囲を示すものであって，手法 自体の有用性を損ねるものではない，つまり，経験的に， HTML ファイルの主要なタグにつけられた情報がページ 内容を代表するような学習リソースは Web 上に数多く 見受けられ，これらに対して有効な支援が可能であると 考えられるためである．こうした学習リソースが統計的 にどの程度あるのかを調査することは必要であるが , こ れについては今後の課題である .

一方, より広範囲の学習リソースに対して, ナビゲー ションパスの見通しをより確実に学習者が得ることがで きるように, ページプレビューを改善することは重要で ある. 产の改善策として, HTML ファイル中の主要なタ グにだけ着目するのではなく, 知的情報検索などの分野 で用いられているページ内容の分析技術を応用し [河野 01]，ページ内容全体を代表する情報をページプレビュー として抽出することがあげられる .

また , Web ページの場合, 必ずしも 1ページに1つの 学習項目ではなく, 複数の項目か記述されている場合も ある [松田 01] . 現在のページプレビューでは，このこと を明確に考慮せず, プレビューされた情報から学習者自 身が学ぶ゙べき項目を選択することに委ねている．しかし 
ながら，より的確なプレビューを生成するという観点か らすれば, どの項目に着目しているのかを判断し, ペー ジプレビューに反映させることが望ましい .このために は, あるページのプレビューを生成する際に,どのペー ジから見通光うとしているのかなどのプラニング文脈を 考慮することが必要となる. 現在 , プラニング文脈の情 報を分類し，ページプレビューの生成方法を検討してい る [長谷川 01] .

\section{6. ま と め}

本論文では，Webにある既存の学習リソースを用いた 主体的学習を支援する上で, ハイパー空間におけるナビ ゲーション過程のモニタリングを促進する重要性につい て述べ , ナビゲーションプラニング支援手法を提案した . 本手法の特徵は, ハイパー空間での学習を, ページ内容 の理解とナビゲーションプラニングに区別し，学習者自 身にナビゲーションパスのプラニングを意識的に行わせ る点にある.このような支援によって，プラニング能力の 向上も期待でき, またハイパー空間ではページ内容の理 解により多くの注意を向けさせることができるため, 学 習を促進することも期待できる .

また，本論文では，この支援手法を実現するシステム についても述べた . 本支援システムでは , ハイパー空間 地图を与えるとともに, 学習者が地図上で選択したペー ジやパスの概要情報を表示するページプレビューおよび パスプレビュー機能を提供し, 学習者がナビゲーション パスの見通しを立てることを補助する枠組みを実現して いる。

また，本支援システムを用いたケーススタディについ ても述べた . 弚の結果, より複雑なハイパー空間におい て，本支援手法は学習者によるナビゲーションプラニン グを有効に支援し , ナビゲーション効率を高める可能性 があることを確認した .

今後は, Web 上にあるより多くの学習リソースについ て実験を行い，本支援手法の有効性を評価する．また，よ り確実に , かつ的確にナビゲーションパスのプレビュー を行う機能を実現することで, 本支援手法を洗練するこ とも今後の重要な課題の一つである.さらに, 本支援シ ステムを継続的に利用させる実験を通して，本支援手法 がナビゲーションプラニング能力の向上にも貢献するこ とを調査したいと考えている .

\section{謝辞}

本研究の一部は (財) ソフトウェア工学研究財団 (RISE) の援助による . また , 本研究を進めるにあたり有益なコ メントをいただいた大阪大学産業科学研究所の LBP 研 究メンバーに感謝する。

\section{$\diamond$ 参 考 文 献 $\diamond$}

[Ausubel 61] Ausubel, D. and Fitzgerald, D.: The role of discriminability in meaningful verbal learning and retention, Journal of Educational Psychology, Vol.52, pp.266-274 (1961).

[Brusilovsky 96] Brusilovsky, P.: Methods and Techniques of Adaptive Hypermedia, Journal of User Modeling and UserAdapted Interaction, Vol.6, pp.87-129 (1996) .

[Cunninghan 93] Cunninghan, D.J., Duffy, T.M., and Knuth, R.A.: The Textbook of the Future, in McKnight, C., Dillon, A., and Richardson, J. (eds): HYPERTEXT A Psychological Perspective, Ellis HorwoodLimited, pp.19-49 (1993).

[Domel 94] Domel, P.: WebMap-A Graphical Hypertext Navigation Tool, Proc. of Second International WWW Conference (1994).

[Fischer 98] Fischer, G., and Scharff, E.: Learning Technologies in Support of Self-Directed Learning, Journal of Interactive Media in Education, 98 (4) (1998).

[Gaines 95] Gaines, B.R. and Shaw M.L. G. WebMap: Concept Mapping on the Web, Proc. of Second International WWW Conference (1995).

[Hammond 93] Hammond, N. Learning with Hypertext: Problems, Principles and Prospects, in McKnight, C., Dillon, A., and Richardson, J. (eds): HYPERTEXT A Psychological Perspective, Ellis HorwoodLimited, pp.51-69 (1993).

[長谷川 01] 長谷川忍, 鈴木亮一, 柏原昭博, 豊田順一: 適応的パ スプレビュー-ハイパー空間における探究学習のためのナビゲー ション支援, 人工知能学会研究会資料 SIG-IES-A101-6, pp.3340 (2001).

[Kashihara 99] Kashihara, A., Ujii, H., and Toyoda, J.: Reflection Support for Learning in Hyperspace, Educational Technology, Vol.39, No.5, pp.19-22 (1999).

[Kashihara 00] Kashihara, A., Suzuki, R., Hasegawa, S., and Toyoda, J. A Navigation Path Planning on the Web, Proc. of IEEE International Workshop on Advanced Learning Technologies, pp.25-26 (2000).

[河野 01] 河野浩之 : 特集「Web システムにおける情報獲得支援 技術」, 人工知能学会誌 Vol 16, No. 4 (2001).

[Kopetzky 99] Kopetzky, T., and Muehlhaeuser, M.: Visual Preview for Link Traversal on the WWW, Proc. of WWW8 (1999).

[松田 01] 松田憲幸, 野本豊裕, 平嶋宗, 豊田順一: Web ブラウ ジングを対象としたページ分割による情報フィルタリング手法の 提案と評価, システム制御情報学会論文誌, Vol.15, No.4 (2001).

[Nielsen 90] Nielsen, J. The Art of Navigating Hypertext, Communication of the ACM, Vol.33, No.3, pp.297-310, ACM Press (1990).

[Suzuki 01] Suzuki, R., Hasegawa, S., Kashihara, A., and Toyoda, J.: A Navigation Path Planning Assistant for Webbased Learning, Proc. of World Conference on Educational Multimedia, Hypermedia \& Telecommunications, pp.18511856 (2001).

[Tauscher 97] Tauscher, L., and Greenberg, S.: How people revist web pages: empirical findings and implications for the design of history systems, International Journal of HumanComputer Studies, Vol.47, No.1, pp.97-137 (1997).

[Thuering 95] Thuering, M., Hannemann, J., and Haake, J.M.: Hypermedia and Cognition: Designing for Comprehension. Communication of the ACM, Vol.38, No.8, pp.5766, ACM Press (1995).

[Zeiliger 99] Zeiliger, R., Belisle, C., and Cerratto, T.: Implementing a Constructivist Approach to Web Navigation Support, Proc. of World Conference on Educational Multimedia and Hypermedia 99 (1999).

〔担当委員 : 伊藤紘二〕

2001 年 11 月 16 日 受理 


\section{著 者 紹 介}

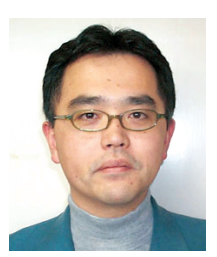

柏原 昭博(正会員)

1987 年徳島大学工学部情報工学科卒業 . 1989 年同大学院 修士課程修了. 1992 年大阪大学大学院博士課程修了. 同年, 大阪大学産業科学研究所助手. 1999 年同講師. 2002 年 同助教授. 1996 年〜1997 年, ドイツ国立研究所 GMD

FIT 客員研究員 . 博士 (工学) . 人間の知性を活かす CHI に興味を持ち,特に学習支援に関する研究に従事. 1993 年度人工知能学会全国大会優秀論文賞, ED-MEDIA'95 優秀論文賞, 1996 年度 $\cdot 1998$ 年度人工知能学会研究将 励賞. IJAIED, AACE, 電子情報通信学会, 情報処理学会, 教育システム情報 学会各会員.

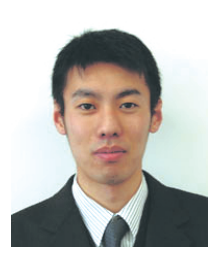

鈴木 亮一(学生会員)

2000 年大阪大学基礎工学部卒業 . 2002 年同大学院修士 課程修了.現在 ,(株) リクルート勤務 . 在学中 , ハイパー 空間における主体的学習に関する研究に従事.

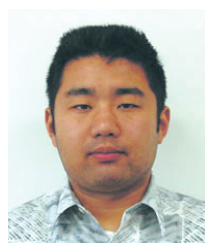

長谷川 忍(学生会員)

1998 年大阪大学基礎工学部卒業, 2002 年同大学院博士 後期課程修了. 同年北陸先端科学技術大学院大学情報科学 センター助手 . 博士 (工学) . ハイパーメディアの教育利 用に関する研究に従事. 1998 年度人工知能学会研究奨励 賞、電子情報通信学会, 教育システム情報学会各会員

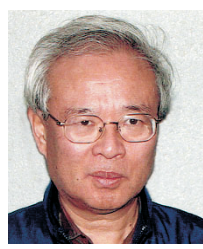

豊田 順一(正会員)

1961 年大阪大学工学部卒業. 1966 年同大学院博士課程 単位取得退学.同年, 同大基礎工学部助手. 1969 年助 教授. 1982 年大阪大学産業科学研究所教授. 2002 年金 蘭短期大学教授. 工学博士.人工知能研究を Enabling Technology と割り切り，新しい知性のモデル作成を目標 とする，電子情報通信学会，情報処理学会，日本認知科学 会各会員. 